\title{
IMPLEMENTASI MODEL KINETIKA REAKTOR MENGGUNAKAN KODE PROGRAM LABVIEW PADA SIMULATOR FUNGSIONAL OPERASI DAN PENGENDALIAN REAKTOR KARTINI
}

\section{IMPLEMENTATION OF REACTOR KINETIC MODEL USING LABVIEW PROGRAM CODE ON FUNCTIONAL SIMULATOR OF KARTINI REACTOR OPERATION AND CONTROL}

\author{
Ikhsan Mahfudin ${ }^{1}$, Adi Abimanyu'1, Syarip² \\ 1Sekolah Tinggi Teknologi Nuklir-BATAN, Jl. Babarsari, Kotak Pos 6101 YKBB Yogyakarta \\ 2Pusat Sains dan Teknologi Akselerator-BATAN, JI. Babarsari, Kotak Pos 6101 YKBB Yogyakarta \\ ikhsanmahfudin@gmail.com
}

Diterima 20 Januari 2020, diterima dalam bentuk perbaikan 23 Maret 2020, disetujui 6 April 2020

\begin{abstract}
ABSTRAK
IMPLEMENTASI MODEL KINETIKA REAKTOR MENGGUNAKAN KODE PROGRAM LABVIEW PADA SIMULATOR FUNGSIONAL OPERASI DAN PENGENDALIAN REAKTOR KARTINI. Implementasi model kinetika reaktor merupakan salah satu usaha untuk membuat suatu rancang bangun simulator fungsional reaktor Kartini. Implementasi yang dimaksudkan adalah untuk memperbaiki hasil pengembangan model kinetika reaktor sebelumnya, dimana masih ditemukan kekurangan pada pemodelan reaktivitas dan hasilhasilnya belum divalidasi. Implementasi ini diharapkan dapat mewujudkan suatu software simulator untuk menggambarkan operasi reaktor Kartini secara lebih nyata sesuai dengan kondisi sebenarnya. Implementasi model kinetika reaktor dilakukan menggunakan perangkat lunak LabVIEW dengan variabel reaktivitas batang kendali, suhu dan peracunan hasil belah, kemudian dilakukan variasi nilai parameter guna memperoleh hasil implementasi pemodelan yang sesuai dengan data operasi reaktor Kartini. Data percobaan diperoleh dengan melakukan variasi terhadap tiga parameter bebas yaitu densitas awal neutron ( $\left.N_{0}\right)$, fraksi kelompok neutron kasip ( $\beta)$, dan massa bahan bakar reaktor $(m)$. Hasil penelitian menunjukkan bahwa perubahan parameter bebas berbanding lurus dengan parameter daya dan periode reaktor. Implementasi pemodelan terbaik terjadi pada percobaan operasi dengan nilai $N_{0}=0,004 ; \beta=0,0014$ dan $m=2563$ gram. Hasil tersebut divalidasi dengan pengukuran parameter daya reaktor dengan tiga data operasi dan memiliki rata-rata akurasi sebesar $86,0 \%$ serta parameter periode reaktor dengan dua data operasi memiliki rata-rata akurasi sebesar $56,6 \%$
\end{abstract}

Kata kunci: simulator fungsional reaktor, kinetika reaktor, reaktor Kartini, LabVIEW.

\begin{abstract}
IMPLEMENTATION OF KINETIC REACTOR MODEL USING LABVIEW PROGRAM CODE ON FUNCTIONAL SIMULATOR OF KARTINI REACTOR OPERATION AND CONTROL. Implementation of the reactor's kinetics model is an attempt to create a functional design of the Kartini reactor simulator. The intended implementation is to improve the results of the development of the previous reactor kinetics model, where there are still deficiencies in reactivity modeling, and the results have not been validated. This implementation is expected to realize a software simulator to describe the operation of the Kartini reactor clearer in accordance with actual conditions. The implementation of the reactor kinetics model was done using LabVIEW software with control rod reactivity, temperature, and product poisoning variables. Then parameter values were varied to obtain the results of modeling implementation by Kartini reactor operation data. Experimental data were obtained by varying the three independent parameters, namely the initial neutron density ( $\left.\mathrm{N}_{0}\right)$, the fraction of the passive neutron group $(\beta)$, and the mass of the reactor fuel $(m)$. The results showed that the change in free parameters is proportional to the parameters of the power and reactor period. The best modeling implementation occurs in an operation experiment with a value of $N_{0}=0.004 ; \beta=0.0014$ and $m=2563$ grams. These results are validated by measuring reactor power parameters with three operating data and have an average accuracy of $86.0 \%$, and reactor period parameters with two operating data have an average accuracy of $56.6 \%$.
\end{abstract}

Keywords: functional reactor simulator, reactor kinetics, Kartini reactor, LabVIEW. 
Jurnal Iptek Nuklir Ganendra

Ganendra Journal of Nuclear Science and Technology

Vol. 23 No. 2, Juli 2020: 47-54

\section{PENDAHULUAN}

Sekolah Tinggi Teknologi Nuklir (STTN) bersama Pusat Sains dan Teknologi Akselerator (PSTA) sebagai Slembaga akademik dan penelitian terus berupaya mengembangkan dan mendayagunakan iptek nuklir. Salah satu fasilitas yang ada adalah reaktor Kartini yang merupakan reaktor tipe TRIGA MARK II yang didesain untuk keperluan pelatihan dan pendidikan. Reaktor ini memiliki izin untuk beroperasi pada tingkat daya $100 \mathrm{~kW}$ meskipun kapasitas daya yang dimiliki sebesar $250 \mathrm{~kW}$ [1]. Dalam rangka pengembangan model pendidikan dan pelatihan yang lebih maju, Nuclear Training Center (NTC) dengan beberapa jenis operasi dapat ditampilkan secara langsung bersamaan dengan operasi reaktor Kartini seperti kalibrasi batang kendali, kalibrasi daya, pengukuran fluks neutron, dan pengukuran koefisien negatif suhu [2]. Pengembangan lainnya masih dimungkinkan untuk dilakukan antara lain pelatihan operasi secara langsung dengan menggunakan alat peraga atau simulator.

Keberadaan simulator pengendalian reaktor menjadi penting karena seseorang yang belum mendapatkan surat izin bekerja tidak boleh secara langsung mengoperasikan reaktor pada ruang kendali utama [3]. Data terbaru menunjukkan bahwa SDM di bidang nuklir yang ada di BATAN sebesar $53,64 \%$ hingga $73,75 \%$ ditinjau dari aspek pendidikan [4]. Secara spesifik, prediksi 5 tahun ke depan terdapat kekurangan SDM sebanyak 112 orang atau $68,29 \%$ dari 164 orang operator yang dibutuhkan [3]. Hal tersebut menunjukkan diperlukannya piranti pendukung guna mempersiapkan kompetensi dan kualitas sumber daya manusia demi menjamin keselamatan dan keandalan operasi reaktor [4].

Menurut Arafa et al (2015) simulator reaktor riset harus mampu membantu operator dapat memahami efek dari beberapa input yang mempengaruhi operasi reaktor [5]. Oleh karena itu, pada umumnya simulator dilengkapi dengan sistem dan analisis transien yang didasarkan pada efek temperatur dan peracunan hasil belah. Penggambaran parameter yang terdapat pada simulator dapat diwujudkan dengan persamaan kinetika reaktor [6]. Perpaduan antara persamaan kinetika reaktor titik dan reaktivitas perubahan posisi batang kendali, reaktivitas, serta temperatur bahan bakar mampu menghasilkan dinamika periode, daya logaritma, daya linier [7]. Salah satu perangkat lunak yang mampu menggambarkan persamaan kinetika reaktor adalah LabVIEW [8]. Selain perangkat lunak, keberadaan perangkat keras dalam simulator juga diperlukan agar operator memahami kondisi yang sebagaimana yang ada pada simulator reaktor Kartini tipe TRIGA Mark II [9]. Salah satu model simulator yang telah dikembangkan oleh Hakim (2018) menggunakan aktuator CRDM dengan kontrol Programmable Logic Controller (PLC) dan perangkat lunak LabVIEW [10]. Akan tetapi, pemodelan belum memperhatikan reaktivitas umpan balik dalam reaktor sehingga hasil yang diperoleh belum mampu menggambarkan parameter di dalam reaktor Kartini secara lebih akurat.

Penelitian ini bertujuan untuk membuat sebuah model kinetika reaktor yang mampu menggambarkan parameter yang ada di dalam reaktor pada prototipe simulator fungsional secara lebih akurat. Pemodelan didasarkan pada persamaan kinetika reaktor, reaktivitas umpan balik suhu dan peracunan hasil belah. Hasil pemodelan divalidasi dengan data operasi reaktor Kartini. Penelitian ini diharapakan mampu meningkatkan pengembangan pengetahuan dan pemahaman terutama operator, calon operator dan masyarakat tentang reaktor nuklir.

\section{METODOLOGI}

\section{Identifikasi Parameter}

Langkah pemrograman kinetika reaktor meliputi beberapa tahap dimulai dengan identifikasi parameter reaktor dan diakhiri dengan validasi hasil pemodelan dengan data operasi reaktor. Pada tahap awal, parameter yang akan digunakan dalam pemodelan diidentifikasi dan diklasifikasikan menjadi parameter konstan, parameter bebas dan parameter terikat. Parameter konstan merupakan nilai yang telah diketahui dan bernilai tetap pada saat program disimulasikan seperti konstanta waktu paruh, tampang lintang serapan, tinggi teras aktif, reaktivitas total batang kendali dan volume reaktor. Parameter bebas merupakan parameter operasi yang nilainya dapat divariasikan sebelum program dijalankan dan pada penelitian ini dilakukan modifikasi terhadap tiga parameter bebas yaitu densitas awal neutron, fraksi kelompok neutron kasip dan massa bahan bakar. Parameter terikat ialah parameter yang akan berubah pada saat program disimulasikan yang dihitung berdasarkan persamaan seperti fluks, daya, periode, reaktivitas dan kosentrasi isotop. 


\section{Implementasi Model Kinetika Reaktor}

Parameter yang telah ditentukan selanjutnya diterjemahkan ke dalam bentuk diagram balok pada Virtual Instrument LabVIEW. Proses yang dijalankan pada diagram balok secara urut ditunjukkan pada Gambar 1. Diagram alir pada Gambar 1 menunjukkan bahwa pada awalnya program komputer akan membaca nilai densitas awal neutron $\left(N_{0}\right)$ dan konsentrasi awal prekursor neutron $\left(C_{0}\right)$.

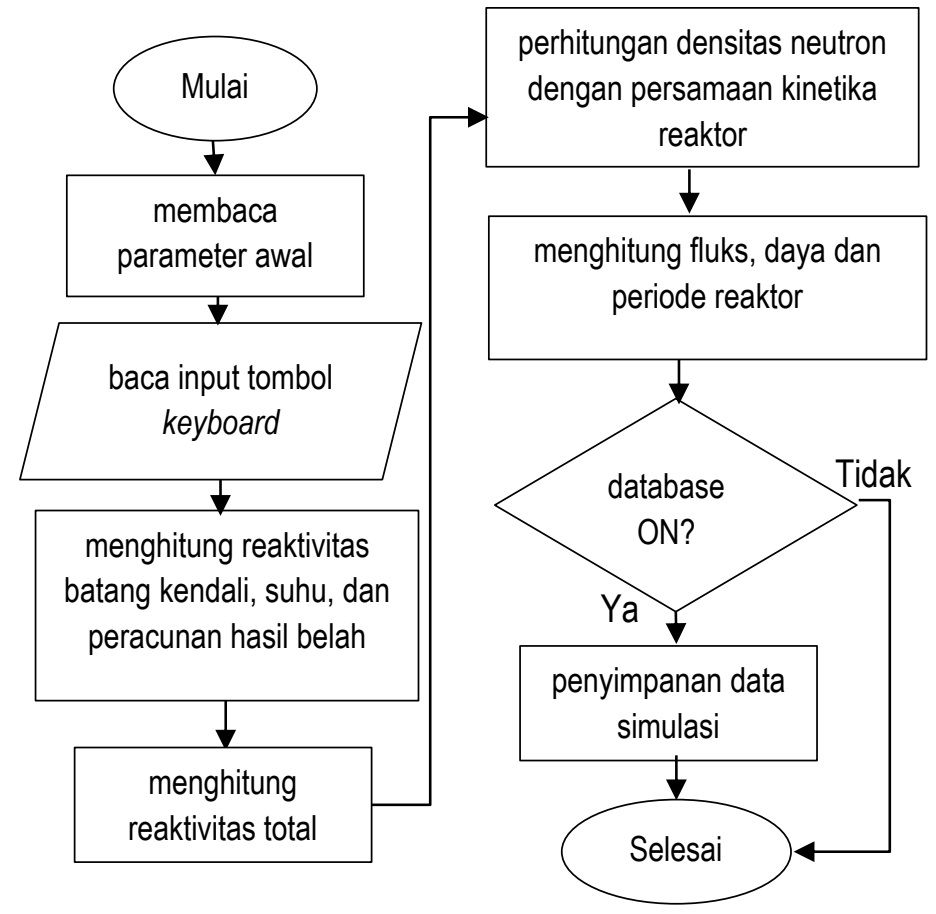

Gambar 1. Diagram alir proses dalam simulasi.

Bagian selanjutnya adalah pembacaan masukan pergerakan batang kendali yang dikendalikan melalui keyboard. Posisi batang kendali kemudian dikonversi menjadi reaktivitas dengan menggunakan persamaan 1 [11]. Daftar simbol yang digunakan pada persamaan (1) sampai dengan persamaan (10) di bawah ini, disajikan pada Tabel 1.

$$
\rho_{w}(\mathrm{x})=\rho_{w}(H)\left[\frac{x}{H}-\frac{1}{2 \pi} \sin \left(\frac{2 \pi x}{H}\right)\right]
$$

Selain reaktivitas batang kendali, reaktivitas lainnya yang digunakan di dalam pemodelan yaitu reaktivitas suhu pada persamaan 2 [12] serta reaktivitas peracunan hasil belah yang dipengaruhi oleh kosentrasi Xenon pada persamaan 3 dan kosentrasi Samarium pada persamaan 4 yang menghasilkan reaktivitas seperti ditunjukkan pada persamaan 5 [13]. Ketiga nilai reaktivitas tersebut kemudian dijumlahkan sebagai nilai reaktivitas total.

$$
\begin{gathered}
\Delta \rho=\alpha_{T F}\left(T_{f}-T_{f 0}\right)+\alpha_{T M}\left(T_{m}-T_{m 0}\right) \\
\frac{d X}{d t}=\lambda_{x} X-\sigma_{x} \phi X+\lambda_{I} I+\gamma_{X} \Sigma_{f} \phi \\
X \frac{d S m}{d t}=\lambda_{P m} P m-\sigma_{S m} \phi S m \\
\Delta \rho=-\frac{X \sigma_{X}}{\Sigma_{a}}-\frac{X \sigma_{S m}}{\Sigma_{a}}
\end{gathered}
$$

Nilai reaktivitas total bersama parameter awal menjadi masukan dalam perhitungan densitas neutron dan konsentrasi perkusor neutron kasip pada persamaan kinetika reaktor titik dengan metode ekspansi deret Taylor menggunakan persamaan 6 dan 7 [14]. 


$$
\begin{gathered}
N(t+h)=N(t)+h \frac{\rho-\beta}{\Lambda} N(t)+h \sum_{i=1}^{6} \lambda_{i} C_{i}(t) \\
C_{i}(t+h)=C_{i}(t)+h \frac{\beta_{i}}{\Lambda} n-h \lambda_{i} C_{i}
\end{gathered}
$$

Hasil perhitungan densitas neutron menjadi dasar pada perhitungan fluks neutron menggunakan persamaan 8 [8]. Nilai fluks neutron selanjutnya digunakan untuk perhitungan daya reaktor menggunakan persamaan 9 [6] dan periode reaktor menggunakan persamaan 10 [9].

$$
\begin{gathered}
\phi(r)=n(r) \cdot v \\
P=\frac{\Sigma_{f} \phi V_{r}}{3,125 \times 10^{10}} \\
T=\frac{1}{\ln \frac{P_{t}}{P_{0}}}
\end{gathered}
$$

Tabel 1. Keterangan simbol yang digunakan pada persamaan (1) s.d. (10).

\begin{tabular}{clcl}
\hline Simbol & Keterangan & Simbol & Keterangan \\
\hline$\rho_{w}(H)$ & reaktivitas akibat insersi batang kendali & $T_{M}$ & suhu pendingin \\
$\mathrm{H}$ & tinggi total teras reaktor & $T_{M 0}$ & suhu pendingin awal \\
$\lambda_{\mathrm{x}}$ & konstanta peluruhan ${ }^{135} \mathrm{Xe}$ & $m$ & massa bahan bakar \\
$\lambda_{I}$ & konstanta peluruhan ${ }^{135} \mathrm{I}$ & $N$ & densitas neutron \\
$\Lambda$ & waktu generasi neutron & $C_{i}$ & konsentrasi perkusor \\
$\gamma_{I}$ & persen hasil fisi atau yield dari ${ }^{135} \mathrm{I}$ & $C_{i}(0)$ & konsentrasi perkusor \\
$\gamma_{X}$ & konstanta peluruhan ${ }^{135}{ }^{\mathrm{X} e}$ & $\rho_{\mathrm{w}}(\mathrm{x})$ & reaktivitas batang kendali \\
$\sigma_{X}$ & tampang lintang serapan ${ }^{135} \mathrm{Xe}$ & $I$ & kosentrasi ${ }^{135} \mathrm{I}$ \\
$\lambda_{P m}$ & konstanta peluruhan ${ }^{149} \mathrm{Pm}$ & $X$ & kosentrasi ${ }^{135} \mathrm{Xe}$ \\
$\lambda_{S m}$ & tampang lintang serapan ${ }^{149} \mathrm{Sm}$ & $\rho$ & reaktivitas \\
$v$ & kecepatan neutron & $\Delta \rho$ & perubahan reaktivitas \\
$V_{r}$ & volume teras reaktor & $P m$ & kosentrasi ${ }^{149} \mathrm{Pm}$ \\
$\sigma_{f}$ & tampang lintang mikroskopik & $S m$ & kosentrasi ${ }^{149} \mathrm{Sm}$ \\
$\Sigma_{a}$ & tampang lintang serapan & $\phi$ & fluks neutron \\
$n_{0}$ & populasi neutron atau daya reaktor awal & $P$ & daya reaktor \\
$\beta$ & fraksi kelompok neutron kasip efektif & $P_{0}$ & daya reaktor sebelum iterasi \\
$h$ & increment waktu & $P_{t}$ & daya reaktor saat iterasi \\
$\alpha_{T F}$ & koefisien reaktivitas suhu bahan bakar & $\Sigma_{f}$ & tampang lintang makroskopik \\
$\alpha_{T M}$ & koefisien reaktivitas suhu pendingin & $N b$ & kerapatan bahan dapat belah \\
$T_{f}$ & suhu bahan bakar & $T$ & periode reaktor \\
$T_{f}$ & suhu bahan bakar awal & & \\
\hline
\end{tabular}

\section{Simulasi Program dan Analisis Data}

Parameter posisi batang kendali, reaktivitas, daya, fluks neutron, periode reaktor, suhu bahan bakar, suhu moderator, waktu (tanggal dan jam) akan direkam dengan tool Merge Signals dan Write To Measurement File pada saat berjalannya simulasi. Data direkam setiap 3 detik untuk menghasilkan data keluaran berupa file dengan ekstensi Ivm. Percobaan simulasi dilakukan dengan mengoperasikan start-up reaktor pada kondisi normal hingga mencapai daya $100 \mathrm{~kW}$. Langkah pertama yaitu dengan menaikkan batang kendali pengaman hingga posisi 100\% dan dilanjutkan dengan menaikkan batang kendali kompensasi hingga posisi $70 \%$. Langkah terakhir yaitu menaikan batang kendali pengatur sehingga daya reaktor mencapai $100 \mathrm{~kW}$. Variasi pada percobaan dilakukan dengan mengubah nilai parameter densitas awal neutron $\left(N_{0}\right)=0,001-0,01$ dengan interval 0,001; fraksi kelompok neutron kasip $(\beta)=0,0007-0,007$ dengan interval 0,0007; dan massa bahan bakar $(m)=2563-2698$ gram dengan 
Implementasi Model Kinetika Reaktor Menggunakan Kode Program LABVIEW pada Simulator Fungsional Operasi dan Pengendalian Reaktor Kartini (lkhsan, dkk.)

interval $27 \mathrm{gram}$. Data percobaan berupa parameter daya dan periode reaktor kemudian dilakukan validasi dengan data operasi reaktor Kartini yang terdapat pada database Internet Reactor Laboratory (IRL) berdasarkan pergerakan posisi batang kendali. Nilai akurasi diperoleh dengan menghitung perbedaan antara data hasil simulasi dan data operasi.

\section{HASIL DAN PEMBAHASAN}

\section{Hasil Simulasi Variasi Parameter Bebas}

Proses pengambilan data dilakukan mulai dari nilai terkecil dari parameter bebas hingga mencapai nilai maksimalnya. Simulasi dijalankan untuk mendapatkan pengaruh parameter bebas terhadap hasil pemodelan serta untuk memperoleh hasil pemodelan terbaik. Analisis pengaruh parameter bebas yang ditampilkan diambil dari daya akibat pergerakan batang kendali pengaman (safety) karena pada beberapa nilai parameter reaktor telah mencapai $100 \mathrm{~kW}$ pada kenaikan batang kendali tersebut.

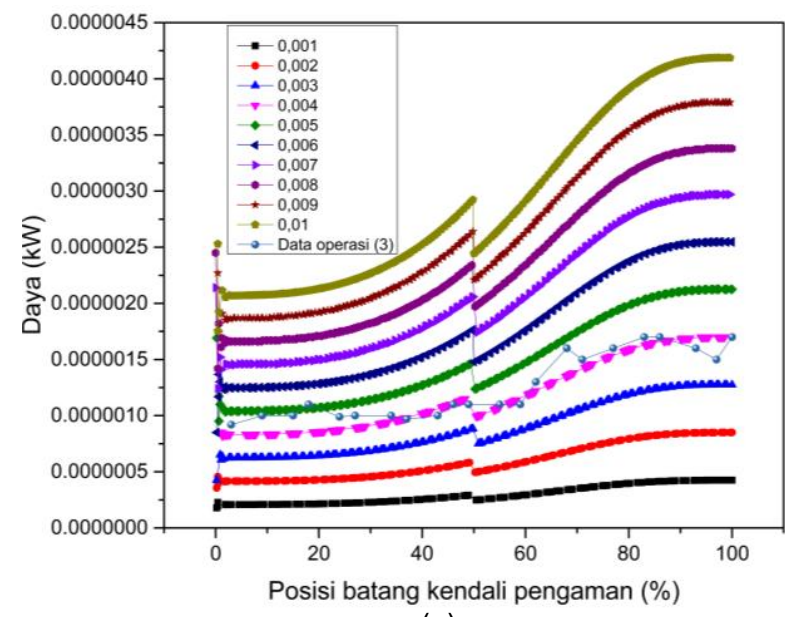

(a)

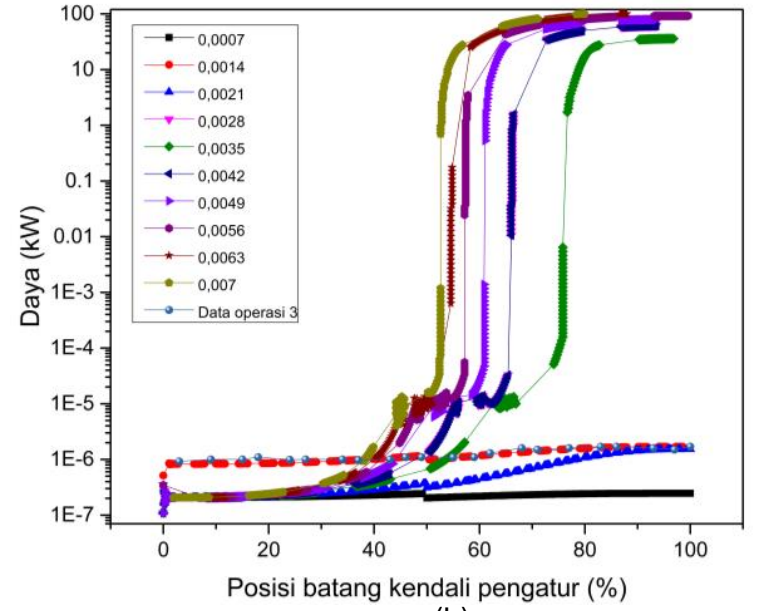

(b)

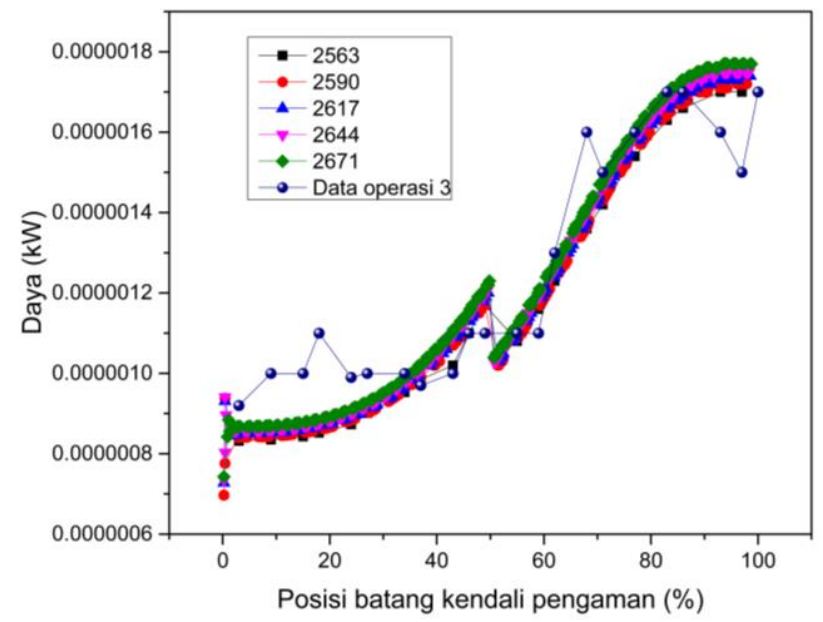

(c)

Gambar 2. Hasil percobaan variasi parameter bebas (a) densitas neutron awal (b) fraksi kelompok neutron kasip (c) massa bahan bakar reaktor.

Hasil simulasi pada Gambar 2(a) menunjukkan bahwa peningkatan nilai denstitas neutron awal $\left(N_{0}\right)$ menyebabkan peningkatan daya reaktor yang dihasilkan. Daya reaktor meningkat secara proporsional sesuai dengan nilai masukan densitas neutron awal. Diskontinuitas data yang terjadi pada posisi batang kendali pengatur karena terdapat nilai parameter reaktivitas yang divariasikan nilainya untuk batang kendali pengatur. Karakteristik peningkatan yang sama juga ditunjukkan pada variasi nilai fraksi kelompok neutron kasip $(\beta)$ sebagaimana pada Gambar 2(b). Peningkatan secara signifikan mulai terjadi pada nilai $\beta=0,0035$. Daya reaktor telah mencapai 100 kW pada saat batang kendali pengaman belum dinaikan sepenuhnya (100\%) pada $\beta=0,0063$ dan $\beta=0,007$. Variasi ketiga yang ditampilkan pada Gambar 2(c) menunjukkan bahwa peningkatan massa bahan bakar reaktor 
Jurnal Iptek Nuklir Ganendra

Ganendra Journal of Nuclear Science and Technology

Vol. 23 No. 2, Juli 2020: 47-54

berbanding lurus dengan peningkatan daya reaktor. Kecenderungan ini sesuai dengan hasil penelitian sebelumnya [15]. Analisis perbandingan dengan data operasi reaktor menunjukkan bahwa hasil pemodelan terbaik yang mendekati data operasi reaktor terjadi pada nilai parameter bebas $N_{0}=0,004 ; \beta=0,0014$ dan $m=2563$ gram, nilai $m$ sangat bersesuaian dengan hasil validasi yang dilakukan penelitian sebelumnya[16]. Hasil pemodelan pada nilai tersebut selanjutnya digunakan sebagai data untuk proses validasi model.

\section{Validasi Model}

Berdasarkan data hasil pemodelan terbaik, validasi dilakukan terhadap 3 data operasi reaktor Kartini pada tanggal 31 Juli 2019 (data operasi 1), 28 Agustus 2019 (data operasi 2) dan 4 September 2019 (data operasi 3). Parameter daya dan periode dibandingkan berdasarkan perubahan posisi 3 batang kendali. Secara umum, performa daya hasil pemodelan menunjukkan data yang sesuai dengan data operasi reaktor Kartini yang ditunjukkan pada Gambar 3. Performa dihitung berdasarkan nilai akurasi yang menunjukkan persen perbedaan antara data hasil simulasi dan data operasi pada posisi batang kendali yang sama. Berdasarkan hasil perhitungan diperoleh akurasi daya pada perubahan posisi batang kendali pengatur sebesar $89,9 \%$, batang kendali kompensasi sebesar $89,8 \%$ dan batang kendali pengatur sebesar $78,4 \%$ sehingga rata-rata validasi parameter daya hasil pemodelan sebesar $86,0 \%$.

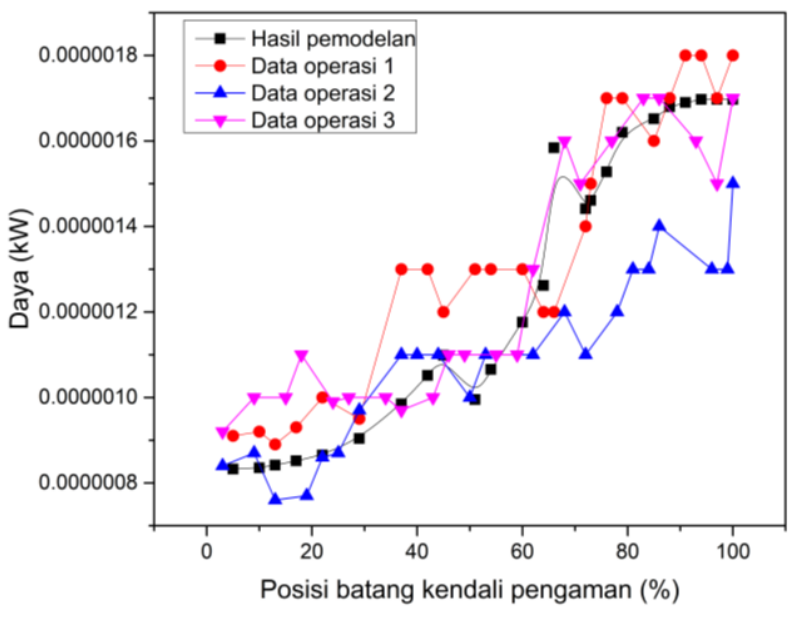

(a)

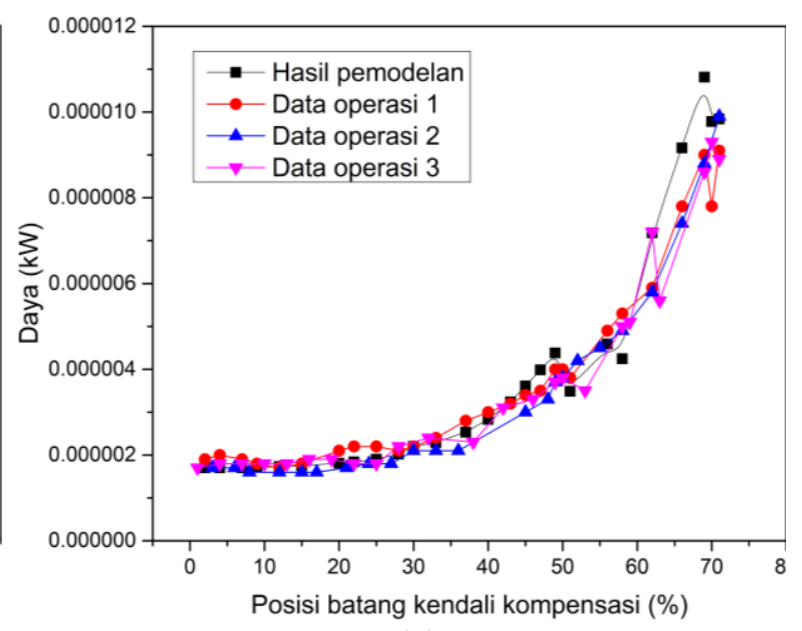

(b)

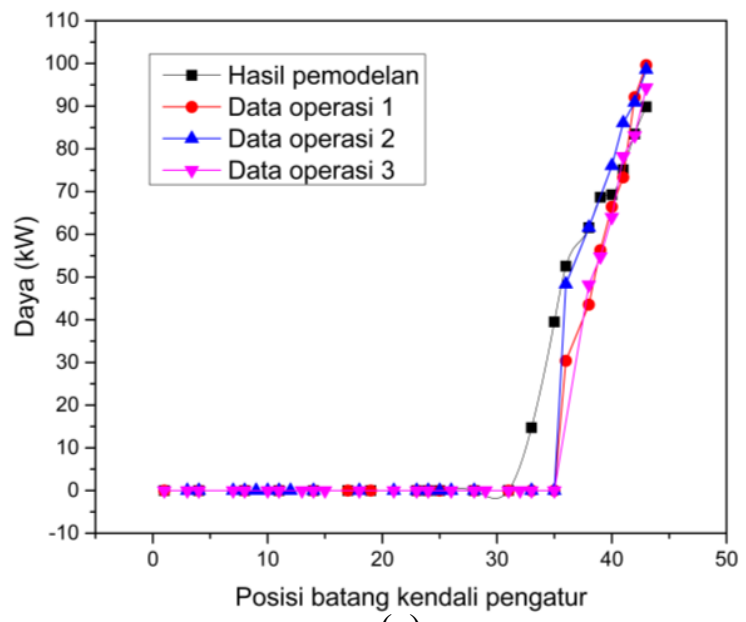

(c)

Gambar 3. Hasil validasi parameter daya reaktor (a) batang kendali pengaman (b) batang kendali kompensasi (c) batang kendali pengatur. 

Pengendalian Reaktor Kartini (Ikhsan, dkk.)

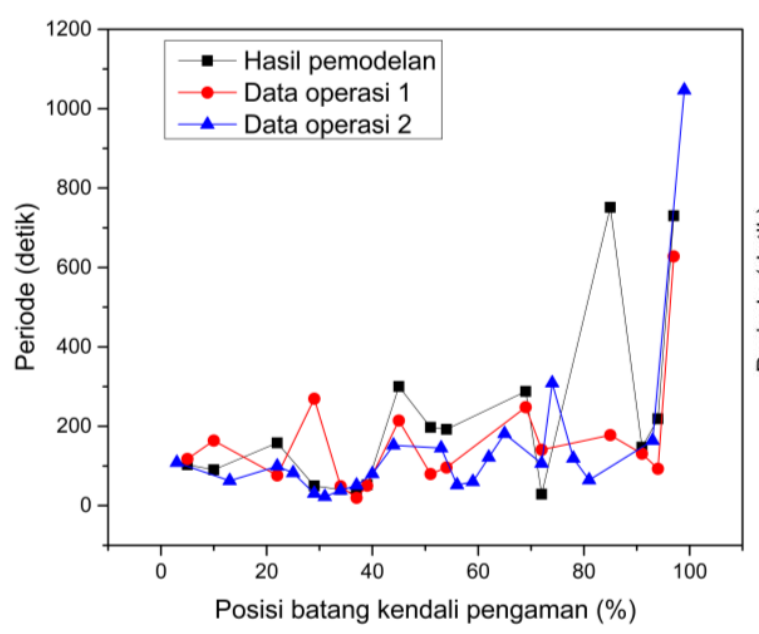

(a)

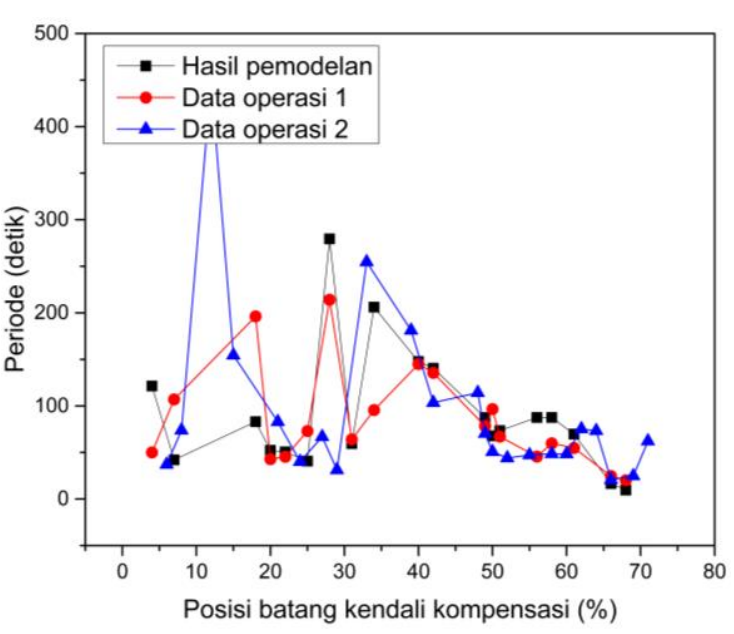

(b)



(c)

Gambar 4. Hasil validasi parameter periode reaktor (a) batang kendali pengaman (b) batang kendali kompensasi (c) batang kendali pengatur.

Berbeda halnya dengan parameter daya, data operasi yang digunakan pada proses validasi hanya data operasi 1 dan 2. Performa periode reaktor hasil pemodelan secara garis besar cukup sesuai dengan data operasi reaktor Kartini seperti ditunjukkan pada Gambar 4. Hasil perhitungan menunjukkan bahwa akurasi periode reaktor pada perubahan posisi batang kendali pengatur sebesar $33,8 \%$, batang kendali kompensasi sebesar $60,7 \%$ dan batang kendali pengatur sebesar $75,1 \%$ sehingga rata-rata validasi parameter daya hasil pemodelan sebesar $56,6 \%$. Nilai tersebut menunjukkan bahwa akurasi periode reaktor lebih rendah dibandingkan akurasi pada daya reaktor karena nilai periode bergantung pada kecepatan pergerakan batang kendali pada saat simulasi.

\section{KESIMPULAN}

Telah berhasil dikembangkan model kinetika reaktor untuk simulator fungsional operasi dan pengendalian reaktor Kartini. Berdasarkan hasil simulasi variasi parameter bebas diketahui bahwa perubahan nilai tiga parameter bebas yaitu parameter densitas awal neutron, fraksi kelompok neutron kasip dan massa bahan bakar berbanding lurus dengan parameter daya dan periode reaktor. Pemodelan terbaik terjadi pada percobaan operasi dengan nilai densitas awal neutron $\left(\mathrm{N}_{0}\right)=0,004$; fraksi kelompok neutron kasip $(\beta)=0,0014$ dan massa bahan bakar $(m)=$ 
Jurnal Iptek Nuklir Ganendra

Ganendra Journal of Nuclear Science and Technology

Vol. 23 No. 2, Juli 2020: 47-54

2563 gram. Hasil tersebut divalidasi pada parameter daya reaktor dengan 3 data operasi memiliki rata-rata akurasi sebesar $86,0 \%$ serta parameter periode reaktor dengan 2 data operasi memiliki rata-rata akurasi sebesar $56,6 \%$.

\section{UCAPAN TERIMA KASIH}

Penulis mengucapkan terima kasih kepada para operator dan supervisor reaktor Kartini serta seluruh staf subbidang Bidang Reaktor Pusat Sains dan Teknologi Akselerator (PSTA) atas kesempatan yang diberikan untuk pengambilan data operasi reaktor dan data lain yang berkaitan dengan reaktor Kartini. Selain itu, penulis mengucapkan terima kasih kepada STTN yang telah mendanai penelitian bersama Unit Penelitian dan Pengabdian Masyarakat (UPPM) melalui DIPA STTN 2020.

\section{DAFTAR PUSTAKA}

[1] T. Suhaemi, D. D. Dj., I. K., J. S., dan Setyono, "Evaluasi Keselamatan Reaktor Kartini Ditinjau dari Desain Sistem Instrumentasi," Presentasi IImiah Teknologi Keselamatan Nuklir VIII, no. 14, pp. 49-60, 2003.

[2] A. Abimanyu, Syarip, E. Supriyatni, Wagirin, D. Gunawan, dan Marsudi, "The Development of Kartini Reactor Data Acquisition System to Support Nuclear Training Centre (NTC)," International Conference ICNERE-EECCIS, pp. 67-70, 2016.

[3] Y. Garini dkk., "Kebijakan Strategis Pengelolaan SDM Operator Reaktor BATAN Operator Reaktor ideal dengan SDM Operator," Seminar Nasional VI SDM Teknologi Nuklir, pp. 80-86, 2018.

[4] M. D. Birmano dan I. Bastori, "Pemetaan dan penyiapan SDM tahap pengoperasian dan perawatan PLTN di indonesia," Seminar Nasional Sains dan Teknologi 2015, vol. 15, pp. 785-793, 2015.

[5] A. Arafa, H. I. Saleh, and N. Ashoub, "Design and implementation progress of multi-purpose simulator for nuclear research reactor using LabVIEW," Kerntechnik, vol. 80, no. 5, pp. 454-464, 2015.

[7] D. Handoyo, A. Cahyono, K. Handono, dan S. Teguh, "Rancang Bangun Perangkat Lunak Simulator Reaktor Nuklir," Jurnal Perangkat Nuklir, vol. 05, no. 02, pp. 106-116, 2011.

[8] A. Cahyono, D. Handoyo, dan K. Handono, "Pemrograman Persamaan Kinetika Reaktor Titik Dengan LabVIEW," PRIMA- Aplikasi dan Rekayasa Dalam Bidang Iptek Nuklir, vol. 9, no. 17, pp. 42-49, 2012.

[9] M. Rosyid dan N. Hidayat, "Simulator Reaktor Kartini Sebagai Alat Peraga Operasi Reaktor Penelitian Tipe Triga Mark II," Seminar Nasional SDM Teknologi Nuklir, pp. 118-124, 2013.

[10] S. U. El Hakim, A. Abimanyu, dan Sutanto, "Simulator Design of Kartini Reactor based on LABVIEW," Jurnal Forum Nuklir, vol. 12, no. 1, pp. 29-41, 2018.

[11] Henryk Anglart, Applied Reactor Technology. Warsawa: Politechnika Warszawska, 2013.

[12] J. Kenneth Shultis and R. Faw, Fundamentals of Nuclear Science and Engineering, January 2008. New York: Marcel Dekker Inc., 2002.

[13] C. Introini, A. Cammi, S. Lorenzi, and G. Magrotti, "An improved zero-dimensional model for simulation of TRIGA Mark II dynamic response," Prog. Nucl. Energy, vol. 111, pp. 85-96, 2019.

[14] B. Mitchell, "Taylor series methods for the solution of the point reactor kinetics equations," Ann. Nucl. Energy, vol. 4, pp. 169-176, 1977.

[15] A. S. Wicaksono, "The Analysis and Performance Test of Kartini Reactor Operation to Provide Neutron Source of SAMOP," Risalah Fisika, vol. 2, no. 1, pp. 21-24, 2018.

[16] A. S. Wicaksono dan Syarip, "Validasi Program Komputer Kekritisan TRIGA-MCNP dengan Percobaan Reaktor Kartini," Prosiding Seminar Nasional Penelitian dan Pengelolaan Perangkat Nuklir, pp. 146-152, 2016. 